\title{
Solitary skull metastasis as the first symptom of hepatocellular carcinoma: case report and literature review
}

This article was published in the following Dove Press journal:

Neuropsychiatric Disease and Treatment

28 April 2014

Number of times this article has been viewed

\author{
Xieli Guo ${ }^{1,2}$ \\ Jiangliu Yin ${ }^{3}$ \\ Yugang Jiang' \\ 'Department of Neurosurgery, \\ Second Xiangya Hospital of \\ Central South University, Changsha, \\ Hunan, People's Republic of China; \\ ${ }^{2}$ Department of Neurosurgery, \\ jinjiang Hospital of Quanzhou Medical \\ College, Jinjiang, Fujian, People's \\ Republic of China; ${ }^{3}$ Department \\ of Neurosurgery, Changsha Central \\ Hospital, Changsha, Hunan, \\ People's Republic of China
}

\begin{abstract}
Skull metastasis from hepatocellular carcinoma (HCC) is reported rarely. In addition, solitary skull metastasis as the first symptom of HCC is reported even less. Here, we reported a case of solitary skull metastasis as the first symptom of HCC and reviewed the literature on skull metastasis. A 49-year-old male patient was admitted to Jinjiang Hospital of Quanzhou Medical College with a painless parietal-occipital scalp mass, and he denied any history of hepatic disease. A cranial computed tomography demonstrated a hypervascular enhancement with osteolytic change in the right parietal-occipital region, cranial magnetic resonance imaging indicated a highly enhanced and osteolytic skull tumor, and abdominal computed tomography showed a huge tumor in the liver. The other examinations showed no other metastases. Laboratory data showed no liver dysfunction while hepatitis B surface antigen was positive, and alpha fetal protein level was high. A craniectomy was performed and the mass was totally removed. The histological diagnosis was skull metastasis from HCC. The patient was subsequently treated by transcatheter arterial chemoembolization. In a review of published literature, the incidence of skull metastasis from HCC in the period between 1990 and 2011 has significantly increased. The misdiagnosis rate of skull metastases as the first symptom from HCC was high. Therefore, it is necessary to give each patient with a scalp mass that has invaded the skull a liver ultrasound or computed tomography scan. On the other hand, we found that metastases that occurred in the calvaria site were more frequent than those that occurred in the skull base and facial skeleton. This may be worthy of further investigation in the future.
\end{abstract}

Keywords: hepatocellular carcinoma, skull metastasis, bone metastasis, positron emission tomography

\section{Case report}

A 49-year-old male visited Jinjiang Hospital of Quanzhou Medical College with the complaint of a painless mass in the right parietal-occipital region of the skull. The mass was found incidentally 1 month earlier by the patient himself and it had grown rapidly. He denied any head traumas or any significant medical problems, including prior history of hepatic disease or chronic alcoholism. Bony window of cranial nonenhanced computed tomography (CT) scan showed a $5 \times 5 \mathrm{~cm}^{2}$ soft tissue mass with irregular destruction (Figure 1A), and contrast-enhanced CT scan showed a hypervascular enhancement with osteolytic pathological change in the parietal-occipital region of the skull (Figure 1B). On admission, neurological and physical examinations revealed no neurological deficits, hepatomegaly, or obvious abnormalities except a painless nonmovable mass about $5 \times 5 \mathrm{~cm}^{2}$ in size over the right parietal-occipital region. Laboratory data showed no liver dysfunction while HBsAg (hepatitis B surface antigen) was
Correspondence: Yugang Jiang Department of Neurosurgery, Second Xiangya Hospital of Central South University, I 39 renmin Middle Road, Changsha, Hunan, 4I00I I, People's Republic of China $\mathrm{Tel} / \mathrm{fax}+86$ I5960795588

Email:yugangjiang123@126.com 


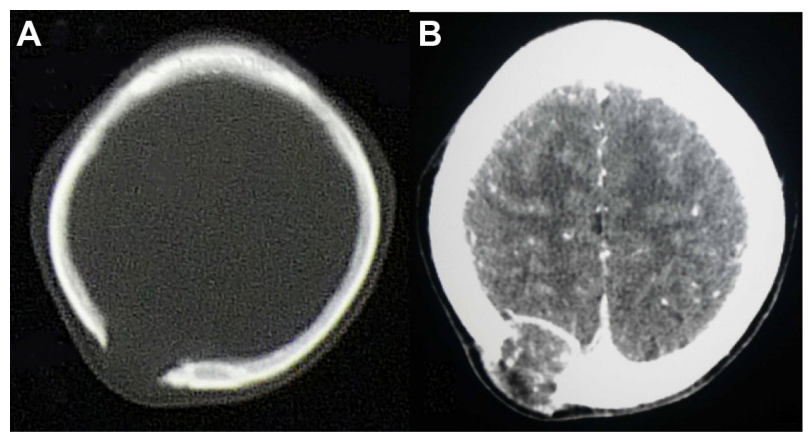

Figure I CT of cranial bones.

Notes: (A) Bony window of cranial CT scan showed a $5 \times 5 \mathrm{~cm}^{2}$ soft tissue mass within the irregularly destructive area of the right parietal-occipital region of the skull. (B) Contrast-enhanced CT scan showed a hypervascular enhancement with osteolytic pathological change in the parietal-occipital region of the skull.

Abbreviation: CT, computed tomography.

positive, and AFP (alpha fetal protein) level was high (Table 1). On cranial magnetic resonance imaging, the tumor was a homogeneous well-defined mass with involvement of the inner and outer skull table. It revealed isosignal intensity on T2-weighted (Figure 2A) and T1-weighted imaging (Figure 2B), with significant enhancement by gadolinium (Figure 2C). Abdominal B ultrasound showed a large mass in the right lobe of the liver (Figure 3); therefore,

Table I Laboratory data on admission

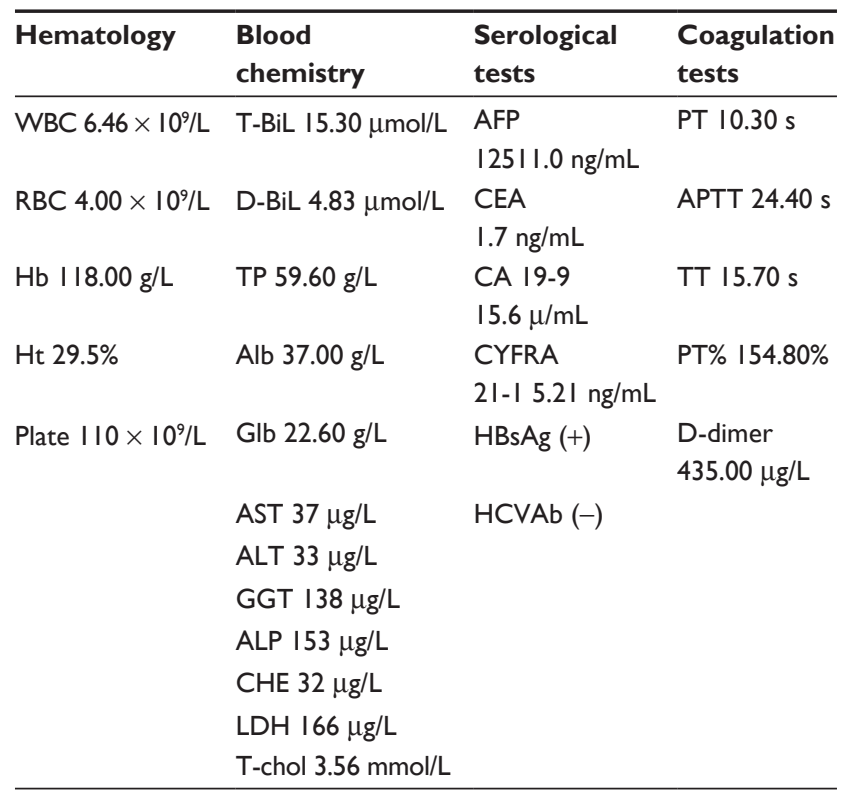

Abbreviations: $\mathrm{Hb}$, hemoglobin; $\mathrm{Ht}$, hematocrit; Plate, platelets; $\mathrm{RBC}$, red blood cells; WBC, white blood cells; T-Bil, total bilirubin; D-Bil, direct bilirubin; TP, total protein; Alb, albumin; Glb, globulin; AST, aspartate transaminase; ALT, alanine transaminase; GGT, gamma glutamyl transpeptidase; ALP, alkaline phosphatase; $\mathrm{CHE}$, cholinesterase; LDH, lactate dehydrogenase; T-chol, total cholesterol; AFP, alpha fetal protein; CEA, carcinoembryonic antigen; CA 19-9, carbohydrate antigen 19-9; CYFRA 2I-I, Cytokerantin-19-fragment CYFRA 2I-I; HBsAg, hepatitis B surface antigen; HCVAb, hepatitis $C$ virus antibody; PT, prothrombin time; APPT, activated partial thromboplastin time; TT, thrombin time; s, seconds.
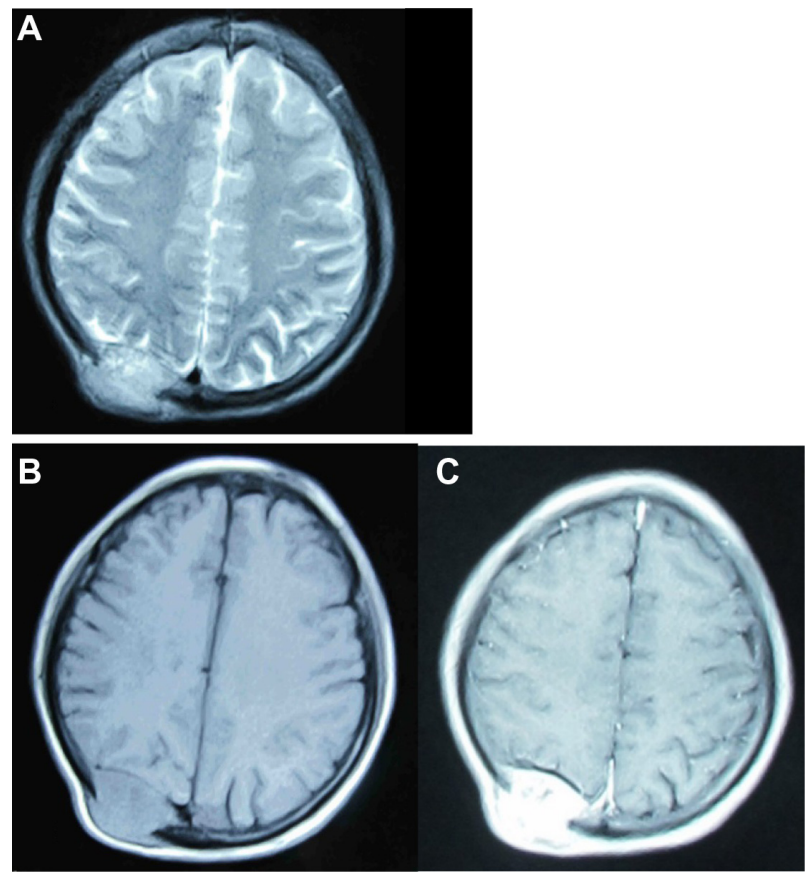

Figure $2 \mathrm{MRI}$ of cranial bones.

Notes: (A) T2-weighted MRI and (B) TI-weighted MRI demonstrated a homogeneous, well-defined, and isosignal intensity carcinoma in the right parietaloccipital region. (C) Gadolinium enhanced TI-weighted MRI images showed a strong enhancement of the carcinoma.

Abbreviation: MRI, magnetic resonance imaging.

a contrast-enhanced CT of the abdomen and a nonenhanced CT of the breast were taken. Contrast-enhanced CT of the abdomen showed a huge enhanced carcinoma in the right lobe of the liver (Figure 4A-C). Nonenhanced CT of the breast showed no lung metastases (Figure 5). A singlephoton emission computed tomography of total skeletal bones showed no metastases (Figure 6). Our diagnosis was

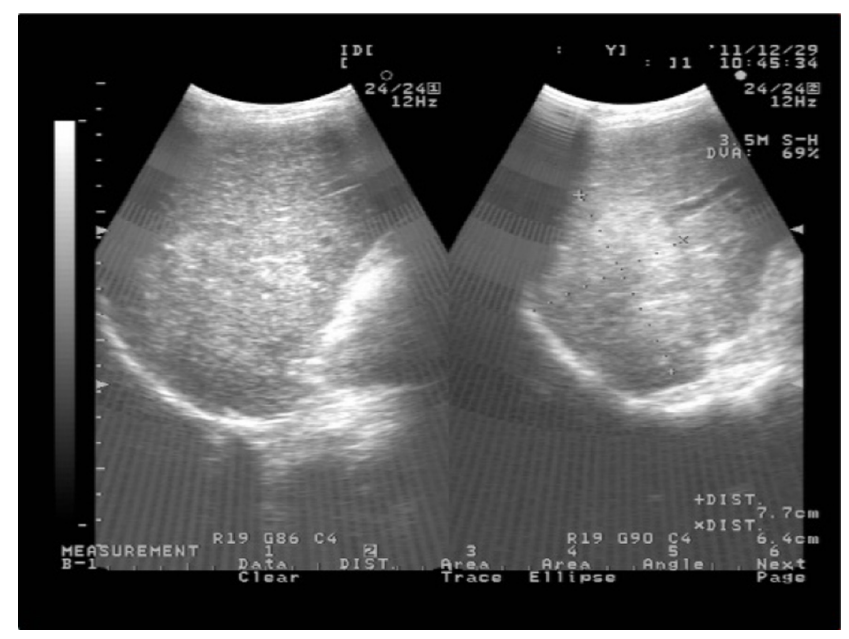

Figure 3 Abdominal B ultrasound showed a large mass in the right lobe of the liver. 


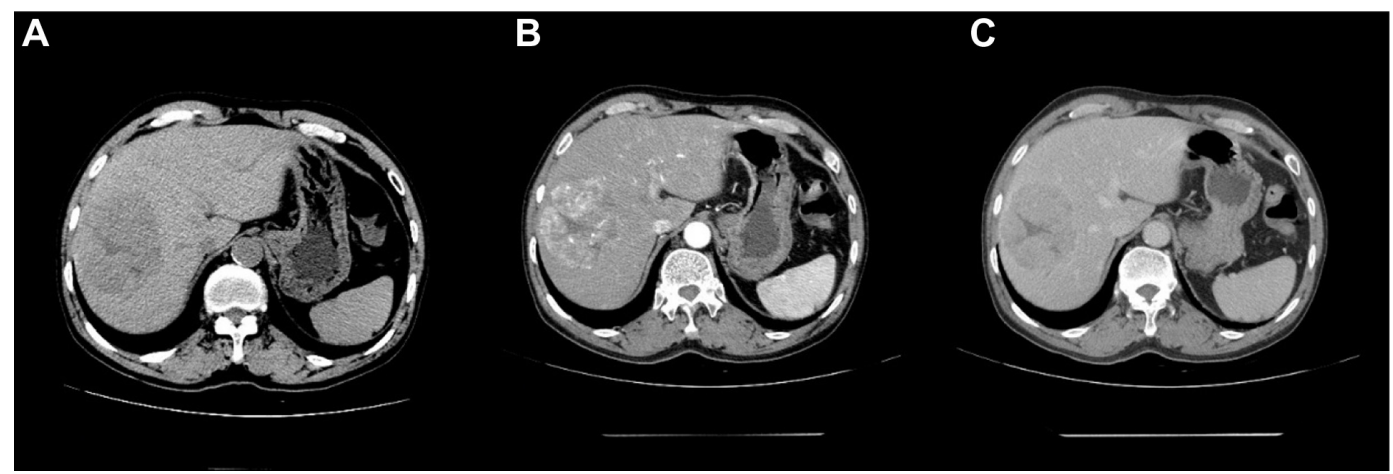

Figure 4 Contrast-enhanced computed tomography of abdomen showed a huge enhanced carcinoma in the liver

Notes: (A) Plain. (B) Arterial phase. (C) Portal phase.

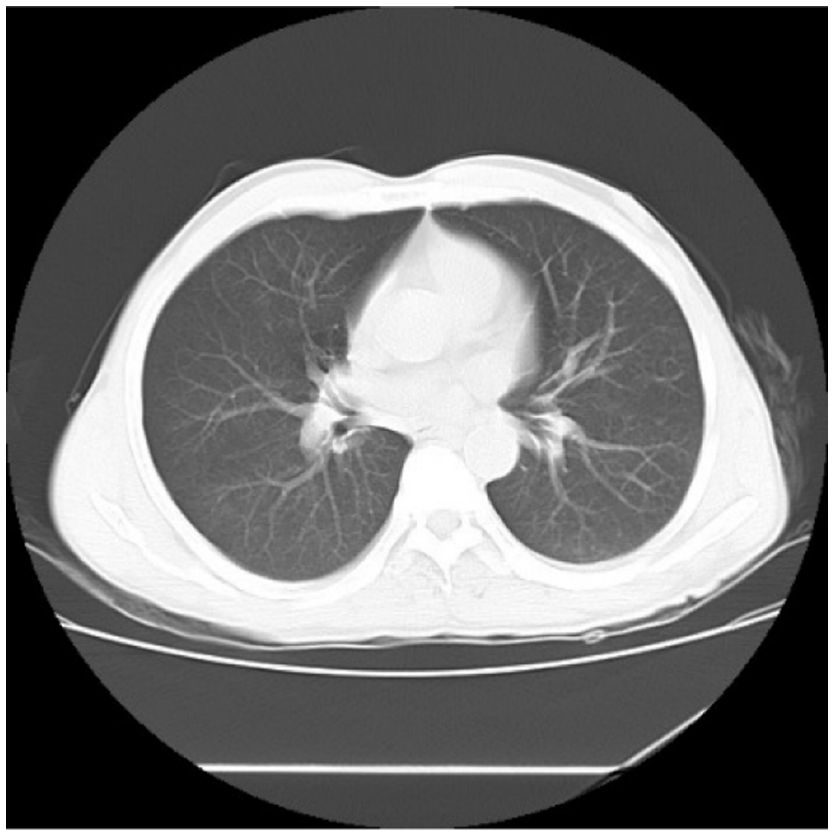

Figure 5 Computed tomography (CT) of breast showed no lung metastases.

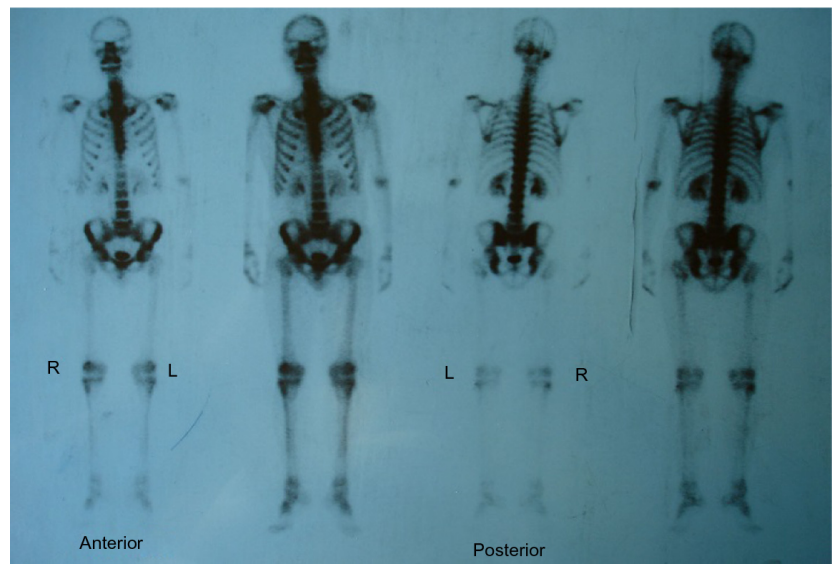

Figure 6 Single-photon emission computed tomography of total skeletal bones showed no other metastases. hepatocellular carcinoma (HCC) with skull metastasis and chronic hepatitis B.

The carcinoma was radically resected with surrounding normal bone via right parietal-occipital craniectomy under general anesthesia. During the operation, a large and well-demarcated reddish-brown mass was found to have penetrated both tables of the skull through the diploic space. The carcinoma looked like cauliflower, and the underlying dura was intact and did not show any evidence of gross carcinoma invasion. The dural surface attached to the carcinoma was curetted and the rough surface of the dura was cauterized by bipolar forceps. The carcinoma was totally removed. Histopathological examination of the carcinoma revealed pleomorphic tumor cells with eosinophilic cytoplasm, and prominent nucleoli and mitosis arranged in trabecular and solid pattern. The pathological findings confirmed the diagnosis of metastasic HCC (Figure 7A and B). Postoperative recovery was satisfactory. To treat the primary carcinoma, transcatheter arterial chemoembolization with pirarubicin $(40 \mathrm{mg})$, carboplatin (200 mg), floxuridine (250 mg), Lipiodol, and Gelatin sponge particles was performed after selecting a feeding artery of the tumor on aortography. The patient was discharged 1 month later. The patient survived after half a year of follow up and did not show any evidence of recurrence in the skull. However, because of the recurrence of hepatocellular carcinomas, the patient died from liver failure in the 18 months since he received transcatheter arterial chemoembolization.

\section{Discussion}

Hepatocellular carcinoma is the fifth most common cancer in the world and is especially prevalent in Africa and East Asia. ${ }^{1}$ The incidence of $\mathrm{HCC}$ in developing countries is 


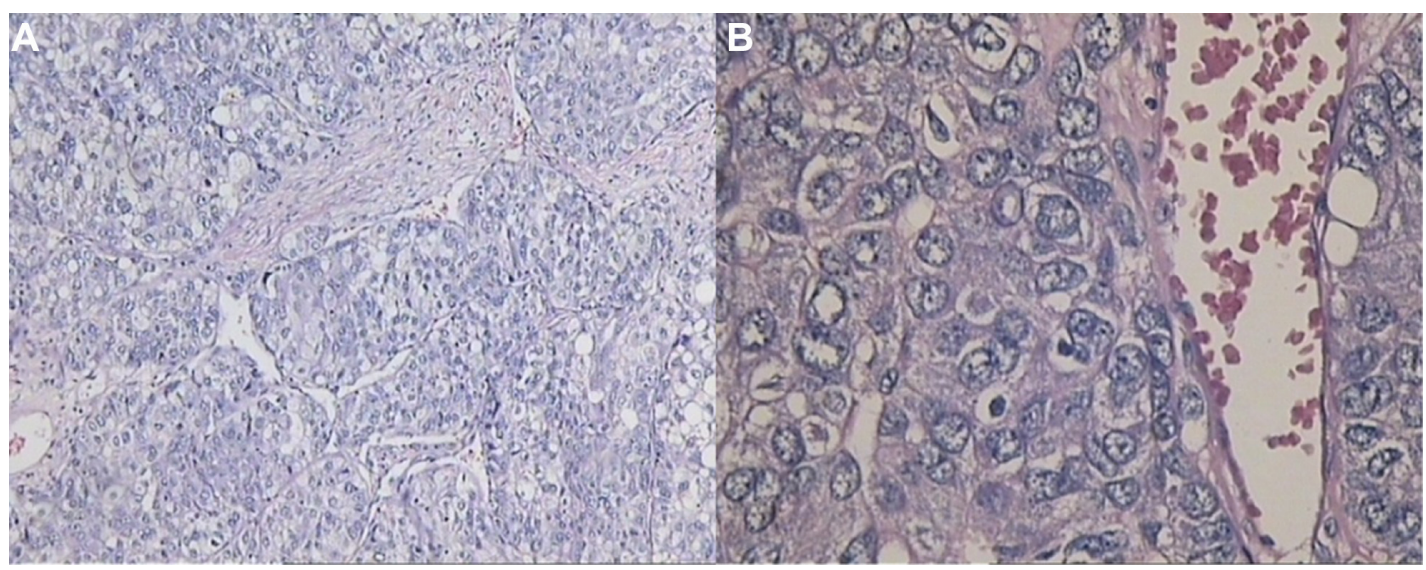

Figure 7 The histopathological characteristics of carcinoma and the immunohistochemical finding.

Notes: (A) Histopathological characteristics of carcinoma. The carcinoma showed thick trabecular growth pattern with intercellular canaliculi resembling liver cell plates and sinusoids. The carcinoma cells maintain a polygonal shape and have abundant granular eosinophilic cytoplasm, round vesicular nuclei, and prominent nucleoli (HE $\times 200)$. (B) The immunohistochemical finding. The carcinoma cells show glypican-3 (+), AFP (-), villin (++), CK7 (-), CK20 (-), vimentin (-), CDI0 (-), and Ki67 (+) of about $30 \%$. Abbreviations: HE, hematoxylin-eosin staining; AFP, alpha fetal protein; CK, creatine kinase; CD, cluster of differentiation or leukocyte differentiation antigen; Ki67, nuclear-associated antigen Ki67.

third most common of the various types of cancer. ${ }^{2}$ Intrahepatic metastasis is the most common metastasis of HCC. Extrahepatic metastases of HCC usually occurs in the regional lymph nodes $(16 \%-40 \%)$ and lungs $(34 \%-70 \%)$, but less commonly in the skeleton $(1.6 \%-16 \%) \cdot{ }^{3-6}$ In skeleton metastasis, HCC usually metastasizes preferentially to the vertebral column, pelvis, femora, and ribs, but rarely to the skull. The incidence of skull metastases from HCC is $0.4 \%-1.6 \%$, , $^{3-5,7,8}$ and $9 \%$ of patients with calvarial metastases have other skeletal deposits. ${ }^{9}$

After a thorough search of the literature, we found 48 articles in total describing patients who were identified with calvaria, skull base, or facial skeleton metastasis from HCC, which formed the basis of this review. In our review of published literature, a total of 59 patients with skull metastasis from HCC were found. . $^{1,3,7,8,10-53}$ The incidence of skull metastasis from HCC in the period between 1990 and 2011 was significantly increased compared to incidence in the period between 1966 and 1989 (45:14, respectively)

Table 2 Summary of reported cases in the literature with skull metastases from HCC $(n=59)^{*}$

\begin{tabular}{lllll}
\hline Period & $\begin{array}{l}\text { Calvarial } \\
\text { metastases }\end{array}$ & $\begin{array}{l}\text { Skull base } \\
\text { metastases }\end{array}$ & $\begin{array}{l}\text { Facial } \\
\text { skeleton } \\
\text { metastases }\end{array}$ & Total \\
\hline $1966-1989$ & 6 & 4 & 4 & 14 \\
$1990-2011$ & 25 & 12 & 8 & 45 \\
Total & 31 & 16 & 12 & 59 \\
\hline
\end{tabular}

Note: *Fourteen cases in the literature with solitary skull metastases from HCC were reported.

Abbreviation: HCC, hepatocellular carcinoma. because of the prolonged survival rate of HCC patients due to the recent progress in both the diagnosis and treatment of the primary lesion after 1990. Metastases occurring in the calvarial site were more frequent than those occurring in the skull base and facial skeleton (31:16:12, respectively) (Table 2). This may be because of the fact that calvarial metastasis are more easily found and HCC cells have more affinity to calvaria. In our review, 24 cases with the skull metastases as the first symptom from HCC (24/59, 41\%) and 14 cases with the solitary skull metastases from HCC $(14 / 59,24 \%)$ were identified (Table 3). In all 24 cases of the skull metastasis as the first symptom from HCC, almost $71 \%$ of these cases were misdiagnosed (17/24). The reason for the high rate of misdiagnosis is that the incidence of skull metastasis of HCC is low and doctors lack a full understanding of this disease. We must pay more attention to such cases in order to reduce the misdiagnosis rate, diagnose as early as possible, and give the patients best treatment to improve their prognosis and quality of

Table 3 Summary of reported cases in the literature with skull metastases as the first symptom from HCC $(n=33)$

\begin{tabular}{lllll}
\hline Period & \multicolumn{2}{l}{ Misdiagnosis* } & Total \\
\cline { 2 - 4 } & $\begin{array}{l}\text { Calvarial } \\
\text { metastases }\end{array}$ & $\begin{array}{l}\text { Skull base } \\
\text { metastases }\end{array}$ & $\begin{array}{l}\text { Facial skeleton } \\
\text { metastases }\end{array}$ \\
\hline I966-1989 & $4(4)$ & $0(0)$ & I (I) & $5(5)$ \\
1990-20II & $10(8)$ & $7(4)$ & $2(0)$ & $19(12)$ \\
Total & 12 & $7(4)$ & $3(1)$ & $24(17)$ \\
\hline
\end{tabular}

Note: *The data in parentheses is the number of patients who were misdiagnosed. Abbreviation: $\mathrm{HCC}$, hepatocellular carcinoma. 
life. Molecular imaging by positron emission tomography is, therefore, set to probe the molecular abnormalities that are the basis of disease and provide different additional biochemical or molecular information about primary brain tumors. ${ }^{54,55}$ In all, it is necessary to give each patient with a scalp mass that has invaded the skull molecular neuroimaging, such as positron emission tomography, to reduce the misdiagnosis rate and to rule out the possibility of skull metastasis from HCC.

\section{Disclosure}

The authors report no conflicts of interest in this work.

\section{References}

1. Hsieh CT, Sun JM, Tsai WC, Tsai TH, Chiang YH, Liu MY. Skull metastasis from hepatocellular carcinoma. Acta Neurochir (Wien). 2007;149:185-190.

2. Tang ZY, editor. Hepatocellular carcinoma. Shanghai: Shanghai Scientific and Technological Education Publishing House; 2001.

3. Chan CH, Trost N, McKelvie P, Rophael JA, Murphy MA. Unusual case of skull metastasis from hepatocellular carcinoma. ANZ J Surg. 2004;74:710-713.

4. Fukutomi M, Yokota M, Chuman H, et al. Increased incidence of bone metastases in hepatocellular carcinoma. Eur J Gastroenterol Hepatol. 2001;13:1083-1088.

5. McIver JI, Scheithauer BW, Rydberg CH, Atkinson JL. Metastatic hepatocellular carcinoma presenting as epidural hematoma: case report. Neurosurgery. 2001;49:447-449.

6. Yen FS, Wu JC, Lai CR, et al. Clinical and radiological pictures of hepatocellular carcinoma with intracranial metastasis. J Gastroenterol Hepatol. 1995;10:413-418.

7. Chang JW, Howng SL. Skull metastasis of primary hepatoma: case report. Gaoxiong Yi Xue Ke Xue Za Zhi. 1991;7:657-662.

8. Murakami R, Korogi Y, Sakamoto Y, et al. Skull metastasis from hepatocellular carcinoma. CT, MR and angiographic findings. Acta Radiol. 1995;36:597-602.

9. Kido DK, Gould R, Taati F, Duncan A, Schnur J. Comparative sensitivity of CT scans, radiographs and radionuclide bone scans in detecting metastatic calvarial lesions. Radiology. 1978;128:371-375.

10. Saneluxsana S, Urathamakul S. Recurrent skull metastasis of hepatocellular carcinoma at 2 month post operation. J Med Assoc Thai. 2010;93 Suppl 6:S212-S214.

11. Fukushima M, Katagiri A, Mori T, Watanabe T, Katayama Y. [Case of skull metastasis from hepatocellular carcinoma at the site of skull fracture]. No Shinkei Geka. 2010;38:371-377. [Japanese].

12. Woo KM, Kim BC, Cho KT, Kim EJ. Spontaneous epidural hematoma from skull base metastasis of hepatocellular carcinoma. J Korean Neurosurg Soc. 2010;47:461-463.

13. Bair MJ, Lei WY, Chen CL. Electronic images of the month. An unusual presentation of hematemesis: a presentation of maxillary metastasis from hepatocellular carcinoma. Clin Gastroenterol Hepatol. 2010;8: e61-e62.

14. Goto T, Dohmen T, Miura K, et al. Skull metastasis from hepatocellular carcinoma with chronic hepatitis B. World J Gastrointest Oncol. 2010;2:165-168.

15. Trivedi P, Gupta A, Pasricha S, Agrawal G, Shah M. Isolated skull base metastasis as the first manifestation of hepatocellular carcinoma: a rare case report with review of literature. J Gastrointest Cancer. 2009;40:10-14.

16. Kanai R, Kubota H, Terada T, Hata T, Tawaraya E, Fujii K. Spontaneous epidural hematoma due to skull metastasis of hepatocellular carcinoma. J Clin Neurosci. 2009;16:137-140.
17. Kim SJ, Kim HJ, Lee HW, et al. [Hepatocellular carcinoma with metastasis to the cavernous sinus of skull base causing ptosis]. Korean J Gastroenterol. 2008;52:389-393. [Korean].

18. Kamatani T, Tatemoto Y, Tateishi Y, Yamamoto T. Isolated metastasis from hepatocellular carcinoma to the mandibular condyle with no evidence of any other metastases: a case report. Br J Oral Maxillofac Surg. 2008;46:499-501.

19. Shim YS, Ahn JY, Cho JH, Lee KS. Solitary skull metastasis as initial manifestation of hepatocellular carcinoma. World J Surg Oncol. 2008;6:66.

20. Hsu SY, Chang FL, Sheu MM, Tsai RK. Homonymous hemianopia caused by solitary skull metastasis of hepatocellular carcinoma. J Neuroophthalmol. 2008;28:51-54.

21. Hirunwiwatkul P, Tirakunwichcha S, Meesuaypong P, Shuangshoti S. Orbital metastasis of hepatocellular carcinoma. $J$ Neuroophthalmol. 2008;28:47-50.

22. Morofuji Y, Matsuo T, Toyoda K, et al. [Skull metastasis of hepatocellular carcinoma successfully treated by intraoperative photodynamic diagnosis using 5-aminolevulinic acid: case report]. No Shinkei Geka. 2007;35:913-918. [Japanese].

23. Huang SF, Wu RC, Chang JT, et al. Intractable bleeding from solitary mandibular metastasis of hepatocellular carcinoma. World $J$ Gastroenterol. 2007;13:4526-4528.

24. Kim SR, Kanda F, Kobessho H, et al. Hepatocellular carcinoma metastasizing to the skull base involving multiple cranial nerves. World $J$ Gastroenterol. 2006;12:6727-6729.

25. Escarda A, Vaquer P, Bonet L, Miralbés S, Gómez C, Obrador A. [Clivus metastasis from hepatocarcinoma associated with transarterial hepatic chemoembolization]. Gastroenterol Hepatol. 2006;29:401-404. [Spanish].

26. De Simone P, Carrai P, Morelli L, et al. Posttransplant hepatocellular carcinoma metastasis at a skull trauma site. Transplantation. 2005;80: $1358-1359$.

27. Kawahara I, Tsutsumi K, Hirose M, Matsuo Y, Yokoyama H. [Skull metastasis of hepatocellular carcinoma: case report]. No Shinkei Geka. 2005;33:903-909. [Japanese].

28. Nam SW, Han JY, Kim JI, et al. Spontaneous regression of a large hepatocellular carcinoma with skull metastasis. J Gastroenterol Hepatol. 2005;20:488-492.

29. Jegou J, Perruzi P, Arav E, Pluot M, Jaussaud R, Remy G. [Cutaneous and bone metastases revealing hepatocarcinoma]. Gastroenterol Clin Biol. 2004;28:804-806. [French].

30. Torres M, Alvarez R, López D, Titó L. Hepatocellular carcinoma skull metastasis with both extradural and subcutaneous extension. J Hepatol. 2002;36:569.

31. Aung TH, Po YC, Wong WK. Hepatocellular carcinoma with metastasis to the skull base, pituitary gland, sphenoid sinus, and cavernous sinus. Hong Kong Med J. 2002;8:48-51.

32. Neff BA, Pribitkin EA, Willcox TO Jr. Hepatocellular cancer metastatic to the zygoma: primary resection and immediate reconstruction. Ear Nose Throat J. 2002;81:57-58.

33. Kleinjung T, Held P. [Metastasis in the frontal skull base from hepatocellular carcinoma]. HNO. 2001;49:126-129. [German].

34. Hayashi K, Matsuo T, Kurihara M, Daikoku M, Kitange G, Shibata S. Skull metastasis of hepatocellular carcinoma associated with acute epidural hematoma: a case report. Surg Neurol. 2000;53:379-382.

35. Isaka T, Nakagawa H, Suzuki T, Yamada J, Wada K, Kadota T. Successful removal of a giant skull base metastasis from hepatocellular carcinoma after direct ethanol injection: case report. Skull Base Surg. 2000;10:81-86.

36. Shibukawa M, Inagawa T, Katoh Y, Tokuda Y, Ohbayashi N, Yoshioka Y. [A case of cranial metastasis of hepatocellular carcinoma]. No To Shinkei. 1995;47:1087-1091. [Japanese].

37. Momoji J, Shimabukuro H, Higa T, Toda T. [A rare case of cranial metastasis from hepatocellular carcinoma]. No Shinkei Geka. 1995;23: 997-1002. [Japanese]. 
38. Raoul JL, Le Simple T, Le Prisé E, Meunier B, Ben Hassel M, Bretagne JF. Bone metastasis revealing hepatocellular carcinoma: a report of three cases with a long clinical course. Am J Gastroenterol. 1995;90:1162-1164.

39. Tranfa F, Cennamo G, Rosa N, De Rosa G, Boscaino A, Bonavolontà G. An unusual orbital lesion: hepatoma metastatic to the orbit. Ophthalmologica. 1994;208:329-332.

40. Yoshida D, Chen MN, Awaya S, Nakazawa S. Cranial metastasis of hepatocellular carcinoma in a female: case report. Neurol Med Chir (Tokyo). 1993;33:839-844.

41. Kato H, Hashimoto M, Kobayashi T, Ohmori K, Fukui T, Sunaga T. [A case of hepatocellular carcinoma with the skull metastasis]. Nihon Shokakibyo Gakkai Zasshi. 1992;89:1319-1322. [Japanese].

42. Nakagawa Y, Yoshino E, Suzuki K, Tatebe A, Andachi H. Spontaneous epidural hematoma from a hepatocellular carcinoma metastasis to the skull: case report. Neurol Med Chir (Tokyo). 1992;32:300-302.

43. Nakao N, Kubo K, Moriwaki H. Cranial metastasis of hepatocellular carcinoma associated with chronic epidural hematoma: case report. Neurol Med Chir (Tokyo). 1992;32:100-103.

44. Knöbber D, Jahnke V. [Metastasis to the ENT area]. HNO. 1991;39: 263-265. [German].

45. Kuratsu J, Murakami M, Uemura S, Ushio Y. Brain and skull metastases of hepatic or pancreatic cancer: report of six cases. Neurol Med Chir (Tokyo). 1990;30:476-482.

46. Kanazawa H, Sato K. Gingival metastasis from primary hepatocellular carcinoma: report of a case and review of literature. J Oral Maxillofac Surg. 1989;47:987-990.
47. Ogasawara H, Inagawa T, Yamamoto M, Kamiya K, Monden S. [Cranial metastasis of hepatocellular carcinoma: case report]. No Shinkei Geka. 1988;16:1479-1482. [Japanese].

48. Nakao S, Sato S, Fukumitsu T, Ogata M, Shirane H. [Cranial metastasis of hepatocellular carcinoma. Report of three cases]. Neurol Med Chir (Tokyo). 1985;25:229-234. [Japanese].

49. Reixach R, Galván P, Lamarca J. [Cranial metastasis and hepatic tumor. Report of an anatomo: clinical case]. Rev Clin Esp. 1983;171:211-213. [Spanish].

50. Yasunaga A, Tsujimura M, Shibata S, et al. Simple metastasis of hepatocellular carcinoma to the skull: a case report. No Shinkei Geka. 1982;10:655-658

51. Chang YC, Chen RC. Craniospinal and cerebral metastasis of primary hepatomas: a report of 7 cases. Taiwan Yi Xue Hui Za Zhi. 1979;78: 594-604.

52. Sarrazin A, Bousquet O, Vaillant JM, Brocheriou C, Trinh-Dinh-Hy. [Mandibular metastasis revealing a hepatoma]. Ann Med Interne (Paris). 1974;125:61-64. [French].

53. Ményé PA, Odoulami $\mathrm{H}$, Atangane S. [Bile-secreting cranial metastasis revealing an undiscovered primary liver cancer]. Bull Soc Med Afr Noire Lang Fr. 1970;15:235-240. [French].

54. Schaller BJ, Cornelius JF, Sandu N, Buchfelder M. Molecular imaging of brain tumors personal experience and review of the literature. Curr Mol Med. 2008;8:711-726.

55. Schaller BJ, Modo M, Buchfelder M. Molecular imaging of brain tumors: a bridge between clinical and molecular medicine? Mol Imaging Biol. 2007;9:60-71.
Neuropsychiatric Disease and Treatment

\section{Publish your work in this journal}

Neuropsychiatric Disease and Treatment is an international, peerreviewed journal of clinical therapeutics and pharmacology focusing on concise rapid reporting of clinical or pre-clinical studies on a range of neuropsychiatric and neurological disorders. This journal is indexed on PubMed Central, the 'PsycINFO' database and CAS.

\section{Dovepress}

The manuscript management system is completely online and includes a very quick and fair peer-review system, which is all easy to use. Visit http://www.dovepress.com/testimonials.php to read real quotes from published authors. 